\title{
LA MUERTE DEL DRAGÓN
}

Mauricio López Noriega*

“¿Lo creerás, Ariadna?-dijo Teseo-. El minotauro apenas se defendió.” Así termina Borges La casa de Asterión, ficción que muestra la otra cara de un acontecimiento que hace de Creta y su civilización un prototipo de cambio al cobrar una individualidad especial; todo el relato se mira a través de los ojos del monstruo, de la experiencia vivida por él, pues es sólo hasta el final que aparece el salvador, encarnado en el hijo del rey Egeo. No es de extrañar: el monstruo es el reverso del héroe; el héroe gana su significado, y su poder, por la muerte del monstruo. Sin Minotauro, Teseo no sería sino un ladrón de doncellas o, en el peor de los casos, una víctima más de aquél; sin embargo, al héroe todo se le perdona: el rapto de Ariadna, su posterior abandono, la muerte del padre fruto de un ensimismamiento -¿una embriaguez?- que inhibe la comunicación y que se traduce, como tantos silencios, en una incorrecta lectura: las velas son negras, han muerto el hijo y la esperanza, queda sólo el suicidio. Pero Teseo se convierte en héroe porque toma del Minotauro una sustancia distinta, sustancia que lo lleva al trono de Atenas y lo diferencia de los demás: se transforma en el héroe del Ática por antonomasia quien penetra en el antro de la bestia, descubre lo desconocido y hace frente a una fuerza primigenia, mítica, para salir triunfante y con una sabiduría distinta - en clave psicológica, el héroe reconoce su sombra y el triunfo es la integración al yo.

* Departamento Académico de Estudios Generales, ITAM. 
¿Quién es, por qué existe Minotauro? Anterior a Teseo debió existir un Minotauro; anterior a Minotauro, yacen los principios del mito, sustrato que da sentido a la relación que se establecerá entre el monstruo y su victimario. El proceso que se desarrolla entre un extremo y el otro del hilo, dentro de un laberinto, se puede entender como el cambio de estadio en la cosmovisión del hombre ocurrido dentro de una cultura determinada. Hay que añadir que Teseo es devoto de Apolo y éste es el primer matador de monstruos. Si ya el binomio héroe-monstruo marca un hito, la figura del dios como matador de deidades monstruosas o caóticas o, con otra palabra, salvador connota una dimensión que transfigura el orden del cosmos. ${ }^{1}$ Dos figuras convergen en un acto que no se repetirá sino por medio del símbolo y que expresan el tránsito de una etapa cultural a otra, conmemorada por la comunicación y el ritual y que, como en el caso de Teseo, explica el traslatio imperii de la cultura matriarcal cretense a la solar y patriarcal de Atenas. ${ }^{2}$ Gran número de civilizaciones, de culturas -porque en un inicio cultura y civilización se confunden, hasta que se accede al análisis y a la teoría, adorno que para estos inicios resulta innecesario- se cifran en este paso crítico, se explican a sí mismas mediante un sacrificio cósmico, una acción salvífica o heroica, o salvífica y heroica, que supone un cambio en las relaciones de los hombres entre sí, entre hombres y naturaleza, del hombre consigo mismo, e incluso del hombre con los dioses o con el Dios.

In principio un monstruo, y es notable constatar cuánto aparece esta determinada representación para el monstruo, imagen específica: la serpiente, y también la serpiente magnificada por el pavor, que es el dragón, serpiente con atributos y rasgos que le confieren la fuerza necesaria para que dicho símbolo funcione como verdadera antítesis del héroe o dios que ha de llegar y que, por ello, vuelve suficiente-

${ }^{1}$ Cfr. Gerardus Van der Leeuw, Fenomenología de la religión, 1975, México, FCE, p. 102-3 (el subrayado es mío).

${ }^{2}$ Cfr. Roberto Calasso, Las bodas de Cadmo y Harmonía, 1990, Barcelona, Anagrama, p. 57. 
mente meritoria su victoria, gesta que por medio del mito se seguirá simbolizando en la celebración ritual. ${ }^{3}$ Serpiente y dragón son, en los inicios, inseparables; el propio vocablo griego $\delta \rho \alpha ́ x \omega v$ significa tanto dragón como serpiente, ya que designa un símbolo universal que en todos los casos tiene una bipolaridad ambigua, extraordinariamente compleja. Que a los dragones la imaginaria popular de muchas culturas les haya dotado de elementos distintos tomados de animales peligrosos (cocodrilos, escorpiones, leones...) manifiesta que representa lo animal por excelencia, simbolizando lo opuesto a la vida; sin embargo, la lucha de un dios, generalmente solar, contra un adversario que por medio de un acto salvador instaura un nuevo orden cosmológico, supone la figura de serpiente o dragón dotado de un poder maléfico, a diferencia de otras culturas, ya que en algunos casos o para representar cierta idea de potencia celeste, creadora, ordenadora, principio activo y demiúrgico, se recurre al dragón como símbolo positivo (por ejemplo en las culturas china, japonesa, celta, azteca). Pero en sentido negativo, ya sea acuático, terrestre o volador, el dragón domina las tres dimensiones físicas habituales, aunque cada una tenga un significado diferente: el acuático se relaciona directamente con la lluvia, los ríos y la fertilidad; el terrestre con los misterios telúricos y la sabiduría mistérica o esotérica, y el aéreo con el cielo y el rayo como potencia elemental y símbolo de poder que anuncia también la lluvia. No obstante, el signi-

${ }^{3}$ Así por ejemplo, el dragón apocalíptico, Satanás es “rojo, con siete cabezas y diez cuernos, y sobre sus cabezas siete diademas" (Ap., 12, 3, que se corresponde con Gn., 3, 15-16); la multiplicidad de cabezas magnifica su dominio, los cuernos su poder y las diademas los medios de que se sirve (riqueza, lujuria, mentira, etc.). En este sentido la palabra dragón simboliza en el Libro de la Revelación su temible poder. Además, “el dragón forma una trilogía con la bestia del mar y la bestia de la tierra, que imitan (al revés) la Trinidad del Padre, del Hijo y del Espíritu Santo” (cfr. René Laurentin, El demonio, ¿símbolo o realidad?, 1998, Bilbao, Desclée de Brouwer, p. 85). En el Ramayana, Ravana, jefe de los demonios o rakshasas es un monstruo de diez cabezas y veinte brazos, con lo cual se hace alusión tanto a su poder como, en otra lectura, a nuestros vicios, defectos y carencias. 


\section{MAURICIO LÓPEZ NORIEGA}

ficado primordial, el más profundo, es el de adversario, potencia que se debe vencer para poder llegar a ser un héroe, sea que se instale un tiempo nuevo, sea que se recupere una princesa o un tesoro. Las imágenes se repiten: la iconografía (cerámica, numismática, pintura y escultura, joyería) y la literatura clásicas abundan, por ejemplo, en el tema del águila que devora la serpiente, motivo harto conocido por nosotros, pero que sorprende al ser tan análogamente exacto con las citas grecorromanas. Homero (Il., XII, 200 s.), Cicerón (De Divinatione, I, 47, 106), Virgilio (En., XI, 746 s.), Ovidio (Met., IV, 362 y 724), y Plinio (N. H., X, V, IV, 2), por mencionar algunos, describen la lucha entre águila contra serpiente y se le otorga cierto carácter ético-antropológico o profético a los pasajes. ${ }^{4}$

Una significación que resulta específicamente importante es el carácter estacional que relaciona al dragón con el ciclo anual de lluvia y sequía y, por ello, con los ritos agrícolas y de fertilidad. En este sentido la lucha del dios salvador contra el dragón adquiere un carácter quizá más definido, más inmediato, que la explicación sencilla del temor natural a las fieras o a los fenómenos que no se comprenden. " $\mathrm{La}$ serpiente simboliza el Caos, lo amorfo, lo no-manifiesto. Decapitarla equivale a un acto de creación, al tránsito de lo virtual y lo amorfo a lo formal." ${ }^{5}$ El acto del matador del monstruo revela este sentido profundo y se manifiesta en el cambio cultural. La lucha entre Indra y Vritra, Marduk y Tiamat, Baal y Yam, y Apolo y Pitón “repetía el tránsito del Caos al Cosmos, actualizaba la cosmogonía”. ${ }^{6}$ Cuando entramos en la esfera de lo que sucede $a b$ initio tocamos un modo diferente de ser y entenderlo todo: es la diferencia entre lo sagrado y lo profano. Cuando se relata una historia sagrada se revela un misterio porque los personajes son dioses o héroes civilizadores y se transita ya en la esfera de lo real por excelencia; el dios no revela un acto profano, un acto que no sea

${ }^{4}$ Cfr. Raymond Chevallier, “Aquila supra draconem”, en Estudios Clásicos 88, vol. Apoforeta, Madrid, ed. Fernández Galiano, p. 339-53, passim.

${ }^{5}$ Mircea Eliade, Lo sagrado y lo profano, 1979³, Barcelona, Labor, p. 53.

${ }^{6}$ Idem, p. 70. 
significativo y real: el mito fundamenta el mundo, es obra divina, creación que estalla de plenitud. ${ }^{7}$ Por la imitación de la figura del dios podemos animar la vida; nos permitimos, asimismo, aniquilar la vida al tomarla para alimentarnos de ella. El dios brinda la clave para relacionarnos de una manera sagrada con la Tierra, tercer integrante de esta relación.

La figura de la Madre Tierra es, evidentemente, común a todas las culturas. De ella provienen los seres terrestres, es la engendradora: vegetación, seres humanos, monstruos y, en ocasiones, hasta deidades. Se lee en el himno homérico a la Tierra (Ad Tellus, 1-3): ${ }^{8}$

A la Tierra cantaré, madre universal de sólidos cimientos, abuela venerable que nutre sobre su suelo todo lo que existe. A ti corresponde dar la vida a los mortales, así como quitársela.

No sólo es el reconocimiento del origen; quizá la filiación se muestra de manera más profunda cuando se la reconoce como el lugar de destino y descanso; al morir debemos, deseamos regresar a ella, pues con la muerte se pone de manifiesto el concepto de autoctonía en su más pura expresión; antiguo testimonio de esto es el Rig Veda (X, 18, 10-11): ${ }^{9}$

Deslízate hacia tu madre, la Tierra, bienhechora de dominios enormes, virgen suave como la lana para quien da una buena recompensa, iy que ella te salve de la nada!

¡Oh, Tierra!, no aplastes, haz una bóveda, sé para él dócil, de fácil llegada y un buen retiro, como para su hijo es una madre.

Con la orilla de tu manto cúbrelo.

${ }^{7}$ Cfr. idem, p. 84-7.

${ }^{8}$ Véase, Inni Omerici, 1975, Fondazione Lorenzo Valla, Arnoldo Mondadori ed., a cura di Filippo Càssola.

${ }^{9}$ Rig Veda, 1989, México, Consejo Nacional para la Cultura y las Artes, col. Cien del mundo, trad. y estudio de Juan Miguel de Mora. 


\section{MAURICIO LÓPEZ NORIEGA}

Punto, pues, de origen y llegada; resulta interesante cuán cercana parece la súplica contenida en el Rig Veda al epigrama de Marcial, quien intercede ante la Tierra, conmovido por la muerte de una pequeña $(\mathrm{V}, 34):^{10}$

Que no cubra el rígido césped sus tiernos huesos; y para ella, Tierra, no seas pesada: no lo fue ella para ti.

Por otro lado, hay que subrayar la honda relación que existe entre la Tierra y la mujer. Que la mujer es el campo lo saben y han sabido todas las poesías en toda época. La tierra es la Madre, tanto en India, como en Egipto, Sumeria, Ugarit, Grecia y Roma, en América y en toda la Europa, desde Rusia hasta Portugal, sin dejar de lado los pueblos de Oceanía. Por oposición, el hombre, que labra a la mujer y la fertiliza para la generación, es el arador, el que trabaja la tierra. La madre Tierra puede tener diversas manifestaciones simbólicas: puede ser la madre amorosa; la doncella, hija de esta madre; ambas; una vieja o abuela; puede ser la madre terrible, sanguinaria, o la Virgen que, aunque fértil, permanece intacta. Aunque se opte por una religión en la que la figura que prevalezca sea la del padre, como poder y voluntad, como forjador de Historia, nunca se podrá negar la presencia constante de la madre, como parto, generación y fertilidad, como intercesora y consuelo. ${ }^{11}$

Sin embargo, resulta particularmente necesario establecer la relación de la Madre Tierra con ciertas hijas suyas como entidades preferentemente femeninas, simbolizadas por dragones o serpientes. Por ejemplo Pitón, 'the great she-dragon', como lo llama Fontenrose, es hija de Gea, como lo menciona Ovidio (I, 434-440): ${ }^{12}$

${ }^{10}$ A. Lejavitzer Lapoujade, El Epigrama en Marcial, (tesis profesional), 1996, México, UNAM, FFYL.

${ }^{11}$ Cfr. Van der Leeuw, op. cit., p. 82-93, y James George Frazer, La rama dorada. Magia y religión, $1980^{7}$, México, FCE, trad. E. y T. Campuzano, p. 457-82.

12 Joseph Fontenrose, The Delphic Oracle, 1978, Berkeley, University of California Press, p. 1. Ovidio, Metamorfosis, 1979, México, UNAM, Bibliotheca 
Luego, cuando la tierra enfangada del diluvio reciente por los soles etéreos y el hondo calor volvió a arder hizo salir especies innúmeras, $y$, en parte, figuras antiguas restauró; en parte, creó nuevos monstruos. Por cierto, ella no querría; mas a ti también, Pitón máxima, te engendró allí, y a pueblos nuevos, desconocida serpiente, eras terror; tanto del espacio del monte tenías.

El dragón, hija* de la tierra y también monstruo marino que cuida las aguas (y las retiene), es manifestación de fertilidad pero esta fertilidad aún no está ordenada. Se debe conseguir el tránsito de sus manos a la esfera humana, ya que tal manifestación, aunque fecunda, no permite al hombre ingresar a la esfera de lo sagrado, de lo formal -ritmo cíclico en donde el hombre participa de la naturaleza y de la divinidad-, y que se logra por vez primera cuando un dios se enfrenta al dragón. Dicho acto tiene repercusiones mayores: ordenar lo femenino, lo agrícola, es cambiar la estructura socio-cultural, porque todo lo vegetal se asocia por naturaleza a la mujer; "el fenómeno social y cultural conocido con el nombre de ‘matriarcado' está vinculado al descubrimiento de las plantas alimenticias por la mujer. Fue la mujer la primera que cultivó las plantas alimenticias. Por tanto, era natural que pasara a ser la propietaria del suelo y las cosechas. El prestigio mágico-religioso y, como secuela de éste, el predominio social de la mujer, tienen un modelo cósmico: la figura de la Tierra-Madre". ${ }^{13}$ Donde predomina un rito agrícola predomina también la figura de la mujer, con su inversión de relaciones en las comunidades; cuando se establecen diferencias entre lo que

Scriptorum Graecorom et Romanorum Mexicana, introd. versión y notas de Rubén Bonifaz Nuño; véase también Pausanias X, VI, 6 (Description of Greece, $1965^{3}$, Harvard, London-Heinemann, Harvard University Press, Loeb Classical Library, vol. IV Phocis-Delphi) y Eliano III, 1 (Varia Historia. Epistolae Fragmenta, 1971, Graz, Akademische Druck-U. Verlagsanstart, ed. Rudolph Hercher, vol. II).

* Como hemos dicho, el dragón es un ser de naturaleza femenina.

${ }^{13}$ Eliade, op. cit., p. 125. 


\section{MAURICIO LÓPEZ NORIEGA}

hace el hombre -guerra, tala de bosques, caza y pesca- y lo que hace la mujer -procreación y crianza, labranza del campo, cultivo de azadasólo se mira a lo que uno y otro están facultados naturalmente para realizar. "No es pereza del hombre, sino relación correcta del poder femenino con aquellas funciones conectadas con el misterio del deve-

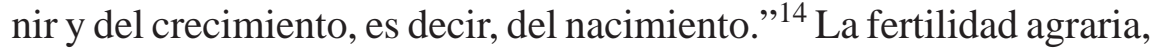
los cultos mistéricos de tipo agrario, el frenesí genésico y la orgía, corresponden a la indiferenciación con lo anterior a la Creación. Cuando el escenario cosmológico-ritual se repite, cuando se regenera el Mundo y se renueva el Tiempo, cuando se reencuentran los escenarios orgiásticos se regresa “a la Noche Cósmica, a lo preformal, a las 'Aguas' para asegurar la regeneración total de Vida y, consiguientemente, la fertilidad de la Tierra y la opulencia de las cosechas”. ${ }^{15}$

Más allá de los contemporáneos discursos sobre género o sobre identidad, a nivel antropológico y socio-cultural el cambio de una etapa a otra se simboliza por el sacrificio de una entidad femenina poderosa, es decir, del dragón o de la serpiente. Lo que esto representa es el cambio en la organización socio-cultural. "Cuando adviene la agricultura, el trabajo de los campos, sembrar y cosechar, pasa a los hombres, porque aquí se emplea el arado y éste no pasa por ser un mecanismo indiferente, sino un falo; allí está en primer término la procreación."16 Procreación en vez de nacimiento, inversión del orden: debe existir la fertilización masculina para dar lugar al nacimiento. No por ello hay que dejar de lado la relación entre la mujer y el campo: esta dinámica entre entidades femeninas cobra sentido religioso; la mujer seguirá siendo la portadora de vida, concibe y da a luz como la tierra. Pero el símbolo profundo que radica en el nacimiento, y que por ello queda ligado naturalmente a la madre, no se opone a un nuevo orden ni sustituye el puesto que ahora el dios solar o el héroe civilizador adquiere, para sí y para los demás, con el conocimiento del orden gestacional.

${ }^{14}$ Cfr. Van der Leeuw, op. cit., p. 198 y 240.

${ }^{15}$ Eliade, idem, p. 126-7.

${ }^{16}$ Van der Leeuw, op. cit., p. 198. 
El monstruo muerto se reintegra a la tierra; el dios solar masculino, ordenador, penetra la sabiduría y la comparte. Este cambio denota, pues, el paso del matriarcado al patriarcado, de las relaciones de la comunidad con el trabajo y la alimentación. En Grecia resulta claro: en las gestas homéricas los varones guerrean y las mujeres se ocupan de la producción y la manutención; en Hesíodo (Erga), en cambio, es el varón quien debe labrar el campo, con conocimiento pleno de los ciclos y de las formas óptimas para relacionarse con la Tierra de manera que el sustento quede asegurado. ${ }^{17}$

Tres figuras preponderantes: la Madre Tierra, el dios solar o, en algunos casos, el héroe civilizador, y el dragón. Relación de filiación directa entre la Madre Tierra y el dragón; relación dinámica entre el dios solar y la Madre Tierra, que se traduce en un enfrentamiento, un choque entre aquel dios y el dragón para poner en movimiento las costumbres de las culturas y su comprensión de los ciclos estacionales que generarán el sustento, pero ya de manera trascendente, sagrada. Ofrezco como muestra cuatro textos de culturas distintas, aunque es importante destacar que no por ello deja de manifestarse en muchas otras, por ejemplo en Egipto, donde también existió el mito de la serpiente primordial o serpiente de los orígenes, Apofis, que encuentra la muerte a manos del dios solar Re; o el cocodrilo infernal de los cuatro puntos cardinales, a quien se conjura en nombre de Set, Osiris, Tem y Ra; o también la serpiente infernal, Apep, a quien vencen las

${ }^{17}$ Aunque, como se detalla más adelante, la lucha de Zeus contra Tifón, dragón de las mil voces, poder de confusión y desorden, también se menciona en la Teogonía se menciona (cfr. Hes., Teog., 820-871). Por ello, "la prueba y la victoria reales, representadas mímicamente conforme al rito mediante una lucha contra un dragón, tienen el valor de una recreación del orden cósmico, estacional, social”. (Jean-Pierre Vernant, Mito y pensamiento en la Grecia antigua, 1973, Barcelona, Ariel, p. 337). 


\section{MAURICIO LÓPEZ NORIEGA}

flechas de Ra. ${ }^{18}$ Asimismo, existe testimonio de la representación del drama de Menfis de la Creación en la piedra ‘Shabako’; en el primer acto del drama se representa la puesta en escena de la batalla cósmica entre Horus y Set, “combate ritual entre el año viejo y el nuevo, entre verano e invierno, entre vida y muerte, lluvia y sequía, etc., la cual encontramos en los festivales estacionales de todo el mundo y que se reproduce en la mitología antigua del cercano Oriente en la batalla entre Baal y Yam (o Mot) en Cannán; o entre el dios de la tormenta y el dragón Illuyankas, entre los hititas; o entre Marduk y Tiamat, entre los babilonios, y entre Yahvé y Leviatán (o Rahab) entre los hebreos”. ${ }^{19}$

El Rig Veda es en su tamaño y proporciones, el documento literario y religioso más antiguo que conserva la humanidad, aunque se estima que quizá algunos documentos egipcios como la Sabiduría de Ptahotep

${ }^{18}$ Cfr. Ángel María Garibay, Voces de Oriente. Antología de textos literarios del cercano Oriente, $1982^{3}$, México, Porrúa, col. sepan cuántos 27, p. 160-1 y 184-5.

${ }^{19}$ Theodor H. Gaster, Thespis. Ritual, Myth and drama in the ancient near East, 1950, New York, Harper \& Row, p. 399-402. Para el Antiguo Testamento serán los grandes monstruos marinos $(\mathrm{Gn} .1,21)$ los prototipos de la bestia por excelencia, el dragón, la serpiente huidiza, Rahab o Leviatán (Is. 27, 1; Job 7, 12; Is. 51, 9). Aquél que personifica al mar en la simbólica de los mitos orientales, se yergue frente al mismo Yahvé como el adversario de su designio de salvación. "En efecto, algunos textos... representan el acto creador de Dios como un combate victorioso contra el monstruo primordial, encarnación del desorden: Rahab o Leviatán (Sal. 74, 13 ss; 89, 10 ss.; Job 9, 13; 25, 12). [...] El primero de estos enfrentamientos es el drama del paraíso (Gn. 3). En el Génesis, el adversario solapado de Dios y de los hombres no es llamado todavía por su verdadero nombre; pero tras la serpiente terrestre se oculta la serpiente prototipo, el dragón, que es el diablo y Satán (Sab. 2, 24; Ap. 12, 9; 20, 2)”, Xavier Léon-Dufour, Vocabulario de teología bíblica, 1966, Barcelona, Herder, s. v. Bestia, bestias. 
y su contemporánea novela de Sinuhé puedan ser algunos años anteriores. ${ }^{20}$ La palabra veda significa ‘saber, conocimiento’ y desde el punto de vista religioso hindú son una verdad revelada. Algunos estudiosos atribuyen al Rig Veda una edad de más de seis mil años; en definitiva, la fecha de composición de sus mil veintiocho suktas no se puede calcular con exactitud, pero el cuerpo religioso que consiste en los cuatro Vedas (Rig, Sama, Yajur y Atharva), que son cada uno a su vez un conjunto de obras o libros, tiene como raíz al Rig Veda. Dividido en diez libros o mandalas, el Rig fue escrito por varios sabios, entre ellos algunas mujeres y en ellos está contenida buena parte de la palabra sagrada hindú, sujeto de miles de interpretaciones; contiene preceptos religiosos, batallas mitológicas, erótica, simposíaca y todo un sistema metafísico verdaderamente extraordinario. Los himnos cosmogónicos que se refieren a la batalla entre el bien y el mal son bastantes y se pueden leer en distintas formas. El personaje central es Indra, dios antropomórfico, dechado de virtudes aunque también muestra rasgos humanos en sus palabras y en sus actos. "El acontecimiento esencial de la mitología de Indra, es su lucha contra Vritra, que era un dragón, una serpiente más bien (...) que retenía las aguas (...). Indra le vence, le mata con su maza de guerra, y las aguas corren libres."21 La interpretación de este acto es polisémica; para algunos, como Gonda, la aparición de Vritra implica un desorden universal que angustia a los mismos dioses; para otros como Lüders, el combate de Indra es un mito de la creación, o mejor aún, del orden del mundo; finalmente, si se interpreta en clave místico-religiosa como Sri Aurobindo, "la batalla que está representada entre los poderes de la luz y de la verdad y los poderes de las tinieblas, es nuestra propia vida (...). En imágenes de la naturaleza física cantan los poetas los himnos de nuestro propio progreso espiritual". 22

${ }^{20}$ Cfr. Rig Veda, estudio de Juan Miguel de Mora, p. 12.

${ }^{21}$ Op. cit., p. 71.

${ }^{22}$ Idem, p. 15-6 y cfr. p. 71-2. 


\section{MAURICIO LÓPEZ NORIEGA}

Es posible ensayar otra interpretación. El pueblo rigvédico era fundamentalmente agrícola y conocía bien los ciclos de la naturaleza más allá de calendarios solares y lunares; conocía la relación entre los rayos solares y el crecimiento de las plantas y cosechas (X, 37, 4); la evaporación (VII, 53, 5), y la importancia de las lluvias (V, 83, 5). Por ello, en el momento en que Vritra retiene las aguas, nace la sequía y se necesita a un dios-salvador que las devuelva para poder subsistir. El combate entre Indra y Vritra es, esencialmente, la reinstauración del orden cósmico y del proceso anual de lluvia-sequía. En muchos himnos se nombra a Indra con el epíteto 'matador de Vritra'23 a diferencia de otros dioses como Apolo, que no necesariamente es matador de Pitón sino 'el que flecha de lejos'. Dos himnos dedicados a este dios, el I, 32 y el I, 80 relatan cuidadosamente la hazaña de Indra, desde que se arma con el soma (lo bebe) hasta la exaltación agradecida del poeta; ambos himnos son parecidos y más o menos largos (15 y 16 estrofas, respectivamente), de manera que el primero bastará.

\section{A INDRA (I, 32)}

Voy a proclamar las hazañas de Indra, las primeras del dios portador del rayo: mató al dragón, atravesó las aguas, las laderas de las montañas reventó.

Mató al dragón que a la montaña se aferraba. Tvastar había forjado para él el sonoro rayo.

Como vacas mugientes, corriendo en dirección al mar, descendieron las Aguas.

Virilmente, había gustado el soma el estrujado líquido bebió en la fiesta de las Tres Barricas. El generoso tomó el venablo, el Rayo: y mató al primogénito de los dragones.

${ }^{23}$ Por ejemplo en III, 41, 4; III, 47, 2; VII, 32, 6; IX, 113, 1; y X, 48, 8. 


\section{LA MUERTE DEL DRAGÓN}

¡Oh, Indra!, cuando al primogénito de los dragones mataste, frustrando las mañas de los maestros en engaños, creando entonces el sol, el cielo, la aurora, desde entonces no has encontrado rival.

Con la gran arma, el rayo, fue como Indra mató a Vritra, poderoso obstáculo de anchos hombros. Como los troncos caen derribados, caído en la tierra yace el dragón.

En una embriaguez maligna, como un guerrero cobarde, había provocado

al gran héroe, bebedor del orujo del soma y valiente cazador. No resistió sus armas y con el carro destrozado se derrumbó el que fue enemigo de Indra.

Luchaba contra Indra sin pies y sin manos pero Indra asestó el rayo sobre su espalda. Eunuco que se creía igual al macho, Vritra yace totalmente despedazado.

Reventado y yacente de mala muerte, pasan sobre él las aguas cuyo valor crece. Vritra cercaba con su gran tamaño las aguas, y ahora el dragón yace a los pies de ellas para lo sucesivo.

Desfalleciente quedó la madre de Vritra:

el arma de la muerte dejó Indra caer sobre ella.

Encima la genitora, debajo estaba el hijo.

Como la vaca cerca del ternero está tendida la maligna.

Entre las corrientes que ni dan tregua ni se detienen, está situado su cuerpo. Las aguas circulan sobre la guarida de Vritra: largas son las tinieblas en las que cayó aquél de quien Indra fue enemigo. 


\section{MAURICIO LÓPEZ NORIEGA}

El dragón es guardián de las esposas del demonio, presas están las Aguas, como las vacas con los Pani. Al matar a Vritra, Indra abrió los desagües, que estaban tapados.

Te convertiste en crin de caballo, ;oh, Indra!, Dios único, cuando en respuesta él te golpeó la mandíbula. Tú conquistaste las vacas, conquistaste el soma, oh, héroe, libraste los ríos de manera que corran.

De nada sirvieron el relámpago y el trueno, ni el granizo ni los nubarrones que el demonio había puesto. Cuando Indra y el dragón combatieron, fue el Generoso quien venció para el futuro.

¿Qué vengador del dragón se te apareció, oh, Indra, para que en tu alma, tú que lo habías matado, penetrase el espanto, y que por encima de los noventa y nueve ríos tú atravesases el espacio como águila atemorizada?

De lo que marcha y de lo que reposa, de lo que no tiene cuernos y de lo que es cornudo, Indra es el rey, él en sus brazos tiene el rayo: como rey manda a los pueblos, y envuelve al mundo como la llanta envuelve los radios de la rueda.

Así como en Sumeria hay una lucha entre Ninurta y el monstruo Asag -preservada en el poema Lugal-e u-me-lam-bi-nir-gal-, que habla de cómo éste permite a las aguas subterráneas amenazar la tierra, y aquél impide el desastre circundando de montañas protectoras y desviando las aguas hacia el Tigris, ${ }^{24}$ así también en Babilonia (-Acadia) se con-

${ }^{24}$ Cfr. Gaster, op. cit., p. 138. 
signó el Poema de la creación o Enuma Elish; ${ }^{25}$ texto que ha sido conservado en seis tablillas (siete, según otros) y que incorpora elementos bastante más antiguos de origen sumerio, aunque su composición haya sido babilónica. El mito relata el origen del orden cosmológico, en el cual el universo está gobernado por un panteón de dioses entre los cuales Marduk es el supremo, y la raza humana existe sólo para servir a los dioses. Pero no siempre fue así; en el principio existían sólo Apsu (las Dulces Aguas primordiales o Abismo) y Tiamat (el Océano), representantes de lo masculino y femenino respectivamente. Mummu es quien completa la tríada primordial como hijo de ambos, aunque no todos los estudiosos están de acuerdo. ${ }^{26}$ La parte que interesa es el combate que finalmente se lleva a cabo entre Marduk y Tiamat. Éste es un monstruo marino que tiene aliados y que ha desafiado a los dioses; Marduk se le enfrenta utilizando sus armas: una lanza, una red, el trueno y el rayo ( $a b u b u$ ), el viento y el huracán. El monstruo, vencido, es cortado en dos para hacer la tierra y el firmamento. Otra versión identifica al monstruo como un dragón llamado Labbu, mientras una tercera habla de un dragón de seis cabezas, e incluso existe otra variante que le otorga siete. ${ }^{27} \mathrm{Al}$ principio de la primera tablilla se dice que Mummu-Tiamat es "la que dio a luz a todos, sus aguas, como un sólo cuerpo, confundían” (I, 4-5) y se relata la generación de los primeros dioses, los cuales se comportan de mala manera pues "perturbaban a Tiamat con su vaivén interminable” y "sus actos eran aborrecibles a Apsu” (I, 22 y 27). Apsu lleva a Mummu con Tiamat para celebrar consejo y le dice a ésta que exterminará a los dioses primogénitos; Tiamat enfurece y tal es el motivo de la lucha contra Apsu y Mummu (I, 29-75). Entonces, mientras estaban vencidos y aprisionados Apsu y Mummu, nace Marduk, hijo de Ea y Damkina, quien será el

\footnotetext{
${ }^{25}$ Enuma Elish, 1989, México, UAM, col. de Cultura Universitaria, trad. y notas de Luis Astey.

${ }^{26}$ Cfr. H. W. F. Saggs, The Greatness that was Babylon, 1962, New York, Mentor, p. 387-90.

${ }^{27}$ Cfr. Gaster, op. cit., p. 89 y 139.
} 


\section{MAURICIO LÓPEZ NORIEGA}

dios por excelencia, dotado de 'doble calidad de ser dios'; es el sol, como lo exclama su padre: “¡Mi hijito, mi hijito! ¡Mi hijo, el Sol! ¡Dios del Sol de los dioses” (I, 102).

Inicia propiamente la lucha contra Tiamat, la cual consta de varias etapas: a) la doble incitación (I, 106a-125); b) la formación de los monstruos (I, 125-146); c) la exaltación de Kingu, lugarteniente de Tiamat (I, 147-161); d) preparativos finales de Tiamat; e) aviso de Ea; f) consulta con Anshar; g) invitación a Ea para que asista a la batalla; h) la invitación a Anu; i) la desesperación de los dioses (II, 1-90). Finalmente se invita a Marduk a que participe en la batalla, pues nadie consigue subyugar a Tiamat; el dios acepta pero pide antes de combatir que su palabra sea inalterable y que maneje los destinos en vez de su padre, es decir, que sea el dios más poderoso. En la tablilla tres se lee una convocatoria a los dioses para luchar e incluye entrevistas con Lahmu y Lahamu y un banquete final preparativo. Es en la tablilla IV donde se relata la batalla. Primero se exalta a Marduk (1-34), quien enseguida se prepara para el combate; afina sus armas: el arco que construye, su maza el relámpago, y llena luego su cuerpo con una flama llameante. Además, forja una red para envolver a Tiamat; produce vientos malignos, al Torbellino y al Huracán, siete vientos en total, para que Tiamat no pueda escapar. Prepara la Tromba y sube a una cuadriga cuyos nombres son Destructor, Inexorable, Arrollador y Veloz (35-58). Y es así como (59-104):

El Señor salió y emprendió su marcha; hacia Tiamat, enfurecida, enderezó su rostro.

Entre sus labios sostenía un conjuro; una hierba para destruir su veneno llevaba apretada en su mano. Entonces a sus lados formaron círculos los dioses, a sus lados formaron círculos; los dioses, sus padres, formaron círculos a sus lados, a sus lados los dioses formaron círculos.

El Señor se aproximó para escudriñar el interior de Tiamat, de Kingu, su esposo, para percibir el designio. 
Observó, y su paso se volvió desconcertado, su voluntad se dispersó y se desordenaron sus actos.

Y cuando los dioses, sus auxiliares, que iban a sus lados, vieron así al valiente príncipe, confusa se hizo su visión.

Tiamat emitió un grito, no desvió su cuello;

en sus labios salvajes formulaba desafío;

"Demasiado importante eres tú para que el

señor de los dioses se levante contra ti.

$¿$ Es en tu residencia en donde ellos se han reunido

$o$ en tu [sic] residencia?”

En ese momento el Señor, levantando la Tromba, su arma poderosa,

a la furibunda Tiamat arrojó la siguiente palabra:

"En cuanto a ti, te has elevado, te has enaltecido arrogantemente;

has encargado a tu propio corazón de promover conflicto,

de tal manera que los hijos rechazan a sus propios padres

al mismo tiempo que tú, que los has dado a luz,

perjuras el amor.

Has designado a Kingu para esposo tuyo;

el rango de Anu, en derecho no suyo, se lo has conferido.

Contra Anshar, rey de los dioses, procuras lo malo;

contra los dioses, mis padres, has afirmado tu malignidad.

Aunque aderezadas se hallen tus fuerzas,

ceñidas tus armas, acércate;

que tú y yo nos encontremos en combate singular”.

Cuando Tiamat escuchó esto,

quedó como poseída, la razón la abandonó.

Enfurecida, Tiamat gritó agudamente.

Hasta sus raíces, las piernas le temblaban ambas juntas.

Ella recitó un conjuro, lanzó su encantamiento,

mientras los dioses de la batalla afilaban sus armas.

Entonces trabaron encuentro Tiamat y Marduk,

el más sapiente entre los dioses,

compitieron en combate singular, acerrojados en batalla. 


\section{MAURICIO LÓPEZ NORIEGA}

El Señor desplegó su red para envolverla;

al Mal Viento, que detrás de él venía, lo desató

contra el rostro de ella.

Cuando Tiamat abrió la boca para consumirlo, él introdujo en ella al Mal Viento

de modo que ella no cerró los labios.

Al cargar sobre su vientre los vientos impetuosos, su cuerpo se expandió, y su boca quedó

ampliamente abierta.

Él soltó la flecha, ésta desgarró su vientre, cortó a través de sus entrañas, hendiendo el corazón.

Habiéndola subyugado así, extinguió su vida.

Derribó su cadáver, y se puso de pie encima de él.

En los versos siguientes, Marduk se encarga de atrapar y aprisionar a la tropa de Tiamat, a su banda de demonios y quita a Kingu las tablillas de los destinos, habidas malamente; para concluir, destroza el cuerpo de Tiamat (IV, 105-134). A continuación, Marduk crea al mundo de nuevo, a partir del cuerpo destrozado de Tiamat y establece ‘una Gran Mansión’ en Esharra e invita a Anu, Enlil y Ea, a que la ocupen (es el cielo; 135-146). En la tablilla VI Marduk fija las estaciones, los astros y la duración del año, lo cual demuestra que un nuevo orden cósmico comienza y que, inmediatamente después de separar cielo y tierra, lo primero que hace el dios civilizador es fijar el ciclo estacional-agrícola, claro ejemplo del tránsito de matriarcado a patriarcado. $^{28}$

${ }^{28}$ Una clara interpretación de esta lucha la ofrece Vernant, op. cit., p. 337-8. 
También la mitología ugarítica está impregnada de luchas por la soberanía divina. En un principio se encuentra el único dios, El, creador del universo y padre de los dioses, benéfico y cosmócrata pero de alguna manera apático -deus otiosus- en su relación con los seres humanos. Por ello, surgirá Baal, hijo de Dagán, que es joven, guerrero, y está más involucrado con la fertilidad cósmica; se le llama 'jinete de las nubes’, 'príncipe señor de la tierra', y ‘poderoso o soberano’. Sus enemigos son Yam ('príncipe o señor del Mar', 'regente del río’); los 'voraces', y Mot (la Muerte). El culto cananeo giraba en torno a dos parejas de dioses: El y Athirat o Asherat, quien también ha sido engendrada por El y que es la 'madre de los dioses' puesto que todos los dioses, salvo Baal, descienden de esta pareja divina, soberanos del otro mundo; y Baal y Anat, deidades de este mundo. La lucha entre Baal y la deidad acuática Yam, monstruo marino, en ocasiones representado antropomórficamente, es el centro del mito. Animado por El, padre suyo, Yam se dispone a arrojar a Baal de su trono, el cual éste había arrebatado a El, sin que encontrara resistencia -se puede identificar a Zeus que castra a Cronos, ya que también Baal castra a El. Baal había insultado a Yam, afirmando que se había elevado presuntuosamente a su posición y que sería destruido. Yam envía a sus mensajeros y exige la rendición de Baal, quien se dispone a guerrear. El herrero divino, Kosharwa-Hasis, prepara dos garrotes mágicos, que tienen la cualidad de dispararse automáticamente de las manos (nada nuevo muestran las mangas japonesas). El primer garrote golpea a Yam en el hombro, pero no lo destruye. El segundo le hiende la frente y el Príncipe del Mar cae por tierra. Baal desea rematarlo y la diosa Ashtart le pide que lo despedace y disperse sus miembros. ${ }^{29}$ El combate entre Marduk

${ }^{29}$ Cfr. Mircea Eliade, Historia de las creencias y de las ideas religiosas. De la prehistoria a los misterios de Eleusis, 1979, Madrid, Cristiandad, p. 168-71 y Gaster, op. cit., p. 114-7. 


\section{MAURICIO LÓPEZ NORIEGA}

y Yam, ‘el dragón de siete cabezas’ se encuentra en las tablillas III AB, A, xii-xviii (Gaster); ofrezco algunas:

\section{XIII}

Así fue arrojada la palabra de su boca, la emisión de sus labios, y ella [Yam] levanta la voz, pero Baal sigue en espera, tendido, a lado del trono del Señor del Mar.

\section{XIV}

Al instante dice el Señor Hábil y Diestro:

"Mira, te he estado diciendo esto, Señor Baal;

date cuenta de esto, ;oh, Jinete de las Nubes!, si a este enemigo Tuyo, oh Baal, si a este enemigo Tuyo matas, si no haces más que destruir al rival, entonces será tuyo este reino por todos los tiempos, y el dominio por todas las generaciones." Enseguida, el Señor Hábil forjó un garrote de la piedra, y pronunció su nombre diciendo:

"iTú, tu nombre es Expulsor (Ygrsh); Expulsor, expulsa al Señor del Mar, expulsa al Señor Mar de su trono, al Regente de los Ríos del asiento de sus dominios.

Brota de la mano de Baal, como un buitre con sus garras hiere al Señor del Mar en el hombro, al Regente de los Ríos sobre la espalda!" Así, el garrote salió de la mano de Baal; como un buitre con sus garras hiere al Señor del Mar en el hombro al Regente de los Ríos sobre la espalda.

No obstante, el Señor del Mar prevalece; no se ha derrumbado; su cresta no se ha combado; su rostro no se ha abatido. 


\section{LA MUERTE DEL DRAGÓN}

\section{XV}

Entonces, (de nuevo) el Señor Hábil creó un garrote de la piedra, y pronunció su nombre diciendo;

“ ¡Tú, tu nombre es Batidor (Aymr);

Batidor, abate al Señor del Mar, abate al Señor del Mar de su trono, al Regente de los Ríos del asiento de su dominio.

Brota de la mano de Baal, como un buitre con sus garras, hiere al Señor del Mar en el cráneo, al Regente de los Ríos entre los ojos, para que el Señor del Mar caiga y se hunda en la grama!”

Así, el garrote salió de la mano de Baal; como un buitre con sus garras hiere al Señor del Mar en el cráneo, al Regente de los Ríos entre los ojos.

El Señor del Mar cae y se hunde en la grama;

su cresta se comba;

y su rostro se abate.

XVI

Al instante, Baal arrastra al Señor del Mar.

Está a punto de descuartizarlo en piezas

para terminar del todo con aquel Regente de los Ríos, cuando Ashtart lo llamó por su nombre

y pronunció un reproche:

“ ¡Avergüénzate, oh Baal, el Poderoso.

Avergüénzate, Tú, el Jinete de las Nubes.

Porque el Señor del Mar es nuestro cautivo común, y fue contra todos nosotros contra quienes iba!"

Sí, entonces Baal se sintió apenado... 
MAURICIO LÓPEZ NORIEGA

\section{XVII}

[Entonces habló] el Señor del Mar:

" ¡Mirad, soy tan bueno como la muerte.

Es seguro que ahora Baal es el rey!"

Sí, entonces Baal se sintió apenado, mientras el Señor del Mar continuaba diciendo:

"iMirad, soy tan bueno como la muerte.

Es seguro que ahora Baal es el rey!”

Se puede ver claramente el carácter estacional de este mito, aun desde los apelativos de cada una de las figuras; el nombre Baal alude a "la victoria de la lluvia contra el mar y las aguas subterráneas; el ritmo pluvial, que representa la norma cósmica, sustituye a la inmensidad caótica y estéril del mar y las inundaciones catastróficas. Con la victoria de Baal triunfa la confianza en el orden y en la estabilidad de las estaciones”. ${ }^{30}$ De esta manera, la interpretación más sencilla es considerar el relato como un mito de la naturaleza; su tema, la alternancia de las estaciones. Después de haber aniquilado a Yam, Baal necesita un templo, que le será construido, al igual que a Marduk. Esto implica ya la dignidad suprema e indiscutible de Baal, y el símbolo profundo del palacio, que es también templo, es una imagen nueva del mundo, su construcción equivale a una nueva cosmogonía. Baal conforma al mundo tal y como lo conocemos. ${ }^{31}$ En su lucha contra Mot, Baal vence también a la muerte; después de haber sido vencido por ella, y de pasar un tiempo en el mundo subterráneo, se recupera y triunfa de nuevo. El carácter de esta otra lucha es el mismo que en su combate contra Yam: "En el esquema de la naturaleza, el reinado de Baal está asociado a la fertilidad y la abundancia, mientras que el reinado de la Muerte significa sequía y hambre.”32

${ }^{30}$ Eliade, idem, p. 172.

${ }^{31}$ Cfr. ibidem y Gaster, op. cit., p. 124-6.

32 Eliade-Couliano, Diccionario de las religiones, 1993, México, PaidósOrientalia, p. 85. 


\section{IV}

En Grecia, el dragón más famoso fue Pitón, serpiente que cuidaba el oráculo de Temis en Delfos pero que, en realidad, se dedicaba a sembrar el caos y a asolar la fértil llanura de Crisa, arrasando las mieses, enturbiando las aguas de manantiales y arroyos y robando el ganado. No sólo hizo esto, sino que incluso, por orden de Hera siempre celosa, cría a Tifón, otra serpiente o monstruo terrible, pues Hera no se explica el nacimiento de Atenea de la cabeza de Zeus sin su concurso, y desea, sola, tener un hijo que vengase la afrenta; invoca a la reunión de dioses del Olimpo, se queja y expresa, llena de ira, su deseo de procrear sin la participación de Zeus; hace una plegaria, golpea con la palma de su mano la tierra y exclama, como narra el Himno homérico a Apolo (334-355):

"Escúchame, Tierra, y tú, amplio cielo que estás sobre nosotros, y ustedes, dioses Titanes que habitan bajo la tierra en el Tártaro inmenso, ustedes, de quienes descendemos hombres y dioses:

escúchenme ahora todos ustedes, dioses, y concédanme un hijo, sin que Zeus participe, que a él no sea inferior en la fuerza, que incluso sea más fuerte que Zeus que mira de lejos, y más fuerte que Cronos."

Pronunciando estas palabras, golpea la tierra con la mano robusta; tiembla la tierra nutricia de vida, y ella, al verla se alegra en el corazón, pues sabe que su deseo será pronto cumplido.

Pasa un año, vuelven las estaciones y tiene al hijo deseado (351-355):

...diferente a dioses y mortales, el terrible, funesto Tifón, flagelo de mortales.

Inmediatamente Hera venerable, la de ojos de ternera, lo toma, 


\section{MAURICIO LÓPEZ NORIEGA}

y lleva el monstruo al monstruo; la dragona lo cría:

y mucho sufrimiento aquél inflingía a la gloriosa estirpe de los hombres. $^{33}$

Finalmente, y después de varias batallas, Zeus conseguirá dar muerte al monstruo. El hijo que heredará su poder será Apolo. El dios solar griego por excelencia, pertenece a la segunda generación de los Olímpicos; hijo de Zeus y Leto, desde el inicio vio sus orígenes complicados por los celos que Hera sentía por aquélla. Finalmente, la esposa de Zeus, que no permitía el alumbramiento, accede mediante el pago de un collar de ámbar y oro, y Apolo nace en la isla Ortigia o Asteria, a la cual en agradecimiento llamó Delos, la brillante, la clara. Inmediatamente, viaja a la tierra de los Hiperbóreos, contra el mandato de su padre que lo quería directamente en Delfos y, luego de permanecer allí cierto tiempo, viaja a Delfos, pues no dejaban sus habitantes de invocarlo con cantos y danzas; llega a Delfos en pleno verano: durante los meses que Apolo está entre los Hiperbóreos, es Dionisio quien señorea en el oráculo. ${ }^{34}$ La mitología griega relaciona a Apolo con las artes, la música y la poesía, con el vaticinio y la medicina, con la inspiración -más mesurada que la dionisíaca-, y también se le reconoce como padre de Pitágoras y se le vincula con la religión órfica, lo cual le da un carácter soteriológico y, en ocasiones, mistérico y esotérico. Una de sus hazañas principales es, evidentemente, haber dado muerte a Pitón y, para conmemorar el hecho, o quizá por temor a la esencia del monstruo, funda los juegos Píticos, juegos fúnebres que fueron bastante famosos, como lo atestigua Ovidio (Met., I, 441-451):

Aésta [a Pitón] el dios que lleva el arco, y de tales armas nunca antes

habiendo usado sino en ciervos y cabras fugaces,

${ }^{33}$ Véase, infra nota 17.

${ }^{34}$ Véase, Pierre Grimal, Diccionario de mitología griega y romana, $1991^{5}$, Barcelona, Paidós, s.v. Apolo, y Eliade, Historia..., p. 286. 
grave de mil dardos, exhausta casi su aljaba, destruyó, habiéndose por llagas negras vertido el veneno. Porque la vejez no pudiera dañar de la obra la fama, de un célebre certamen instituyó sacros juegos, Pitios llamados por el nombre de la domada serpiente. Con manos o pies o rueda, cualquiera, aquí, de los jóvenes que había vencido, tomaba el honor de la fronda de encino; todavía no había lauro, y, hermosas del luengo cabello, con cualquier árbol Febo ceñía sus sienes.

Pero Apolo sabía desde niño cuál era su verdadera misión; en realidad, lo que buscaba Apolo era crear un oráculo para los hombres, que le diera poder sobre ellos y la admiración de los dioses; así lo relata su Himno homérico:

Puesto que yo deseo levantar un espléndido templo que sea oráculo para los hombres, quienes a mí siempre me rindan hecatombes perfectas, cuantos habitan el Peloponeso fecundo, cuantos habitan la Europa, y las islas de mar circundadas, deseosos de consultar el oráculo: y a todos los que vengan mi consejo infalible

daré, dando respuestas en el pingüe templo. (287- 293)

como también Eurípides:

Hermoso es el hijo de Leto, a quien ésta parió en los fructíferos valles de Delos, el de pelo de oro entendido en la cítara y en el tiro certero del arco con que se complace. Llevólo ella misma de junto al acantilado-dejando el ilustre lugar de su parto- hasta la cumbre del Parnaso, de torrenciales aguas, que danza en honor de Dionisio. Allí la serpiente de moteado lomo, de color de vino, cubierta con sombrío laurel de buenas hojas por coraza, el monstruo portentoso de la tierra, vigilaba el oráculo soterráneo. Todavía 


\section{MAURICIO LÓPEZ NORIEGA}

un bebé, todavía palpitando en los brazos de tu madre querida, lo mataste, oh Febo, y ascendiste al divino oráculo y ahora te sientas en áureo trípode, en el trono veraz, vaticinando para los mortales desde el fondo del templo vecino de la corriente de Castalia, y ocupando un palacio que es centro de la tierra. ${ }^{35}$

Apolo se apodera del templo de Temis y consagra un trípode en el santuario. Desde los inicios se entiende al trípode como un instrumento mágico, prodigioso y sagrado; por ello también se le llama a Delfos ‘ombligo del mundo', como lo consigna Varrón (L. L., VII, 17): “Además, si esa parte central es el ombligo de la esfera terrestre, el centro de la esfera no es Delfos. Y el centro de la tierra -no el centro real, sino el que así denominan- es, en Delfos, un edificio que tiene el aspecto de un depósito del tesoro ubicado en el santuario, en uno de los lados, y al que los griegos llaman ' $\mu \phi \alpha \lambda$ ó $\varsigma$, y que pretenden que es la tumba de Pitón."36

Una de las interpretaciones de que Delfos sea el centro es su evidente relación con un nuevo orden para los griegos, que va de la mano con la naturaleza solar de Apolo: "El mar es lo continuo, la perfección de lo indiferenciado. En la tierra su emisario es la serpiente. Allí donde está la serpiente mana el agua. Su ojo es líquido. Bajo sus anillos, corre perenne el agua del subsuelo. Ágil, no necesita articulaciones. Las mismas manchas se repiten sobre toda la piel, las escamas son uniformes, el movimiento ondulante como las olas se renueva siempre."37 Por eso Apolo debe matar a Pitón; dado que cielo, mar e inframundo ya tenían propietarios, quedaba como lugar de dominio la tierra. Al matar a Pitón, Apolo aspira a la perfección completa, proporciona un

35 Eurípides, I.T., 1235-1259 (Tragedias, 1978, Madrid, Gredos, introd. trad. y notas de José Luis Calvo, tomo II).

${ }^{36}$ Varrón, De lingua latina libri XXV , Barcelona-Madrid, Antrophos-Ministerio de Educación y Ciencia, introd., trad. y notas de Manuel Antonio Marcos Casquero.

${ }^{37}$ Calasso, op. cit., p. 190. 
epicentro al nuevo orden: "El ombligo es el punto, el punto único, el indispensable, donde lo perfecto se une a la perfección de lo indiferenciado. Es el pie de Europa en el mar.”38

¿Pero qué quiere decir esto? En realidad, esta mitología agresiva, como todas las otras, marca el cambio de una etapa a otra. Es la forma en que Apolo sustituye paulatinamente a las divinidades griegas prehelénicas. Al instalarse en Delfos, al instaurar un centro, el centro, después de dar muerte al dragón, Apolo simboliza la nueva autoctonía y soberanía primordial que ahora es suya y ya no más de la serpiente. Sin embargo, también por este acto Apolo debe purificarse, es decir, debe lavar la mancha asesina: tabula rasa, el tiempo comienza de nuevo, y además, proporciona a los hombres la oportunidad de acceder, también ellos, a la purificación ( $\varkappa \alpha \theta \alpha ́ \rho \sigma \iota \varsigma$ ) de la mancha que adquieren cuando comen de la tierra de manera profana, o cuando existe un homicidio. Gracias a Apolo, Orestes pudo hacerse perdonar el crimen de matricidio (cfr. Esq. Eum., passim).

Que Apolo haya tomado para sí y reordenado la potencia y la sacralidad de la Madre Tierra se pone de manifiesto con mayor claridad en la fiesta de los Bufonia: “durante un sacrificio público, un tal Sopatro, que no era originario de la región pero que labraba la tierra en el Ática, depositó en el ara, a la vista de todos, para sacrificarlos a los dioses, una torta y otros dulces, cuando llegó un buey, que regresaba del trabajo y devoró una parte de las ofrendas y pisoteó otra. Furioso por lo que ocurría y, visto que alguien, no lejos de allí, estaba afilando un hacha, la cogió y la descargo sobre el buey. Muerto el buey, cuando se le fue la furia, tuvo conciencia del acto que había realizado. Entonces sepultó al buey, y escapó por voluntad propia al exilio, en Creta, como si fuera culpable de impiedad; llegó la sequía, con una terrible penuria de frutos. La Pitia contestó a la delegación que había ido a consultar al dios que el exiliado en Creta pondría fin a esta situación, y que, si hubieran castigado al ejecutor y hubieran vuelto a poner de pie a la víctima en el transcurso del mismo sacrificio en que había muerto, las cosas habrían

${ }^{38}$ Ibidem. 


\section{MAURICIO LÓPEZ NORIEGA}

ido mejor, siempre que comieran al muerto sin escrúpulo alguno. Entonces se dedicaron a buscar a Sopatro, responsable de los hechos. Sopatro estimó que se libraría de esta penosa situación en que lo colocaba su impureza, si todos hubieran actuado como él. Así que manifestó a los que habían ido a buscarle que un buey debía ser abatido por la ciudad. Al sentirlos indecisos en elegir quién debería matar al animal, se ofreció a hacerlo él mismo, si le aceptaban como ciudadano y preparaban en común la ejecución. Se pusieron de acuerdo y, de vuelta a la ciudad, prepararon la acción del siguiente modo, que ha permanecido igual hasta nuestros días. Eligieron unas doncellas como aguadoras: llevan el agua para afilar el hacha y el cuchillo. Cuando estuvieron afilados, otro llevó el hacha, un segundo golpeó al buey, y un tercero lo degolló; después de lo cual lo despellejaron y todos comieron del buey. Después de haber hecho todo esto, cosieron la piel del buey, lo llenaron de paja y lo pusieron de pie, en la misma posición que tenía cuando estaba vivo, y después lo uncieron a un arado, como si trabajara. Pasaron a continuación al juicio por la muerte, y todos los que participaron en la acción pasaron a justificarse. De todos ellos, las aguadoras señalaron como los más culpables a los que habían afilado las hojas, mientras que los que habían afilado las hojas indicaron al que había llevado el hacha, y éste acusó al que lo había degollado, y quien lo había hecho señaló al cuchillo. Este último, que carecía de voz, fue acusado de la muerte (...). Después de haber llenado la piel del buey y haber comparecido en el proceso, arrojaron el cuchillo al mar". ${ }^{39}$

La conciencia del acto, de la culpa de haber transgredido el orden sagrado por el acto profano queda así conjurada y sacralizada por el ritual. Mediante toda una compleja ceremonia, en la que participa toda la comunidad, el buey, que ara el campo, es comido por quienes recibirán el fruto de la tierra, pero ya como un acto trascendente. Lo mismo sucede, como renovación del ciclo de sequía y plenitud, con la historia de Carilla, despreciada por el rey de Delfos y que se ahorca. Para reparar

${ }^{39}$ Véase, Teofrasto, Sobre la devoción, fr. 18, y Porfirio, Sobre la abstinencia, II, 29-30. 
el daño, pues la escasez apremia, recurren a la Pitia: el oráculo indica que se deben reconciliar con Carilla, "la virgen suicida” (Plut. Quaest. Graec., 293e); repiten, ahora ya con conciencia, el sacrificio que habían llevado a cabo sin saberlo, y nace de nuevo la prosperidad.

El dragón es la figura primigenia del caos y de la preponderancia femenina sobre y dentro de la comunidad, por su relación naturalmente íntima con la Madre Tierra; el dios ordenador, mediante la muerte del dragón renueva el ritmo cósmico, ordena las estaciones, vuelve las aguas a su cauce y, sobre todo, nos permite llevar a cabo la labranza de la tierra y reorganizar la sociedad, ahora ya bajo el predominio masculino, aunque sin dejar de reconocer que siempre la mujer tendrá una relación particularmente estrecha con la tierra. ¿Antigua sabiduría reducida a mitos, a leyendas?

Salvo en nuestros días, prácticamente durante cualquier época se ha reconocido esta relación y este cambio; hoy, quizá porque las sociedades se han vuelto preferentemente urbanas, tal vez ya no se alcanza a comprender el significado del símbolo y no se lo celebra más, como aún se hace en ciertos medios rurales; sin embargo, ni siquiera de manera indirecta se alcanza a relacionar su riqueza con nuestra vida, con nuestra experiencia. Pero el hombre es un 'animal simbólico' y esto es una realidad objetiva; por ello, el dragón, como todo símbolo profundo, opera a distintos niveles y de diferentes formas. Desde la psiquiatría y el psicoanálisis lo han puesto de manifiesto Jung et al. Además de a éstos, parece que sólo siguen interesando los símbolos a los semiólogos y a los estudiosos de las religiones. No obstante, para el hombre común y corriente, y sin caer en histerismos new age, quizá quede un resabio de interpretación que pudiera alcanzarse; podrían percibirse estos mismos mitos estacionales-agrícolas, esta muerte del dragón, como integrantes de un proceso interior, espiritual: el dragón representa la parte oscura de uno mismo que impide nuestra armonía; 


\section{MAURICIO LÓPEZ NORIEGA}

por ende, la parte solar, luminosa, ordenada de la personalidad ha de activarse dando muerte a la zona o faceta caótica, de tal manera que el proceso espiritual (o psico-dinámico) de la persona se desarrolle de manera sana y progresiva. En este sentido, creo, el símbolo del dragón, del monstruo, del ser que no reconocemos ni podemos integrar como nuestro por su naturaleza negativa, puede seguir aportando un valor de significado, como con lucidez lo han percibido poetas y escritores:

Todos los dragones de nuestra vida son posiblemente princesas que esperan vernos bellos y valientes. Todas las cosas sin socorro no son posiblemente sino cosas sin socorro que esperan ser socorridas por nosotros.

(R. M. Rilke, Cartas a un joven poeta, VIII).

-Es extraño. Cada uno se construye su sendero, es su sendero. ¿Por qué, entonces, los obstáculos? ¿Llevamos el Minotauro en el corazón, en el recinto negro de la voluntad? Cuando ordené al arquitecto esta sierpe de mármol era como si previera la irrupción del cabeza de toro. Y también como si tu barca, ;oh matador de sueños crueles!, estuviera ya subiendo el río, toda velas negras, hacia Cnossos. ¿Es que vamos extrayendo el acaecer de nuestro presente torturado? ¿Edificamos tan horriblemente nuestra desdicha?

(J. Cortázar, Los Reyes, Escena segunda). 